DOE/NV/13609--08

\title{
COMPARISON OF NEAR-FIELD AND FAR-FIELD AIR MONITORING OF PLUTONIUM-CONTAMINATED SOILS FROM THE TONOPAH TEST RANGE, NEVADA
}

\author{
prepared by \\ John L. Bowen and David S. Shafer \\ submitted to \\ Nevada Operations Office \\ National Nuclear Security Administration \\ U.S. Department of Energy \\ Las Vegas, Nevada
}

MAY 2001

Publication No. 45181 
Reference herein to any specific commercial product, process, or service by trade name, trademark, manufacturer, or otherwise, does not necessarily constitute or imply its endorsement, recommendation, or favoring by the United States Government or any agency thereof or its contractors or subcontractors. The views and opinions of authors expressed herein do not necessarily state or reflect those of the United States Government or any agency thereof.

This report has been reproduced directly from the best available copy.

Available for sale to the public, in paper, from:

\section{U.S. Department of Commerce}

National Technical Information Service

5285 Port Royal Rd.

Springfield, VA 22161

phone: 800.553 .6847

fax: 703.605.6000

email: order@ntis.fedworld.gov

online ordering: http://www.ntis.gov/ordering.htm

Available electronically at http://www.doe.gov/bridge

Available for a processing fee to the U.S. Department of Energy and its contractors, in paper, from:

U.S. Department of Energy

Office of Scientific and Technical Information

P.O. Box 62

Oak Ridge, TN 37831-0062

phone: 423.576 .8401

fax: 423.576 .5728

email: reports@adonis.osti.gov 
DOE/NV/13609--08

\title{
COMPARISON OF NEAR-FIELD AND FAR-FIELD AIR MONITORING OF PLUTONIUM-CONTAMINATED SOILS FROM THE TONOPAH TEST RANGE, NEVADA
}

\author{
Prepared by \\ John L. Bowen \\ Division of Atmospheric Sciences \\ and \\ David S. Shafer \\ Division of Hydrologic Sciences \\ Desert Research Institute \\ University and Community College System of Nevada \\ Publication No. 45181 \\ Submitted to \\ Nevada Operations Office \\ National Nuclear Security Administration \\ U.S. Department of Energy \\ Las Vegas, Nevada
}

May 2001

The work upon which this report is based was supported by the U.S. Department of Energy under Contract \#DE-AC08-00NV13609. Approved for public release; further dissemination unlimited. 


\section{EXECUTIVE SUMMARY}

Operation Roller Coaster, a series of nuclear material dispersal experiments, resulted in three areas (Clean Slates 1, 2, and 3) of widespread surface soil plutonium (Pu) contamination on the Tonopah Test Range (TTR). TTR is located $225 \mathrm{~km}$ (140 miles) northwest of Las Vegas, Nevada, within the Nellis Air Force Range. In support of remediation of these sites by the U.S. Department of Energy, National Nuclear Security Administration, Nevada Operations Office, the Desert Research Institute (DRI) conducted background air monitoring prior to excavation of any contaminated soils from the Clean Slate sites. The State of Nevada, Division of Environmental Protection, has raised concerns that dispersal of airborne Pu particles from the Clean Slate sites could result in undetected deposition farther downwind than the DRI background air-monitoring site for the Clean Slate sites. To begin addressing this issue, two existing sets of air monitoring data that characterized the airborne particles with aerodynamic diameters less than $10 \mu \mathrm{m}\left(\mathrm{PM}_{10}\right)$ at different distances from the Clean Slate sites but during the same period of time were compared.

The two sets consisted of 1) the results of air monitoring conducted by DRI between February 1996 and January 1997 to establish background conditions for airborne mass concentration and $\mathrm{Pu}$ contamination in the $\mathrm{PM}_{10}$ particle size range in the vicinity of the Clean Slate test locations and 2) the results of particulate sampling conducted by Sandia National Laboratories (SNL) between February 1996 and February 1997 to collect airborne samples of airborne $\mathrm{PM}_{10}$ mass and $\mathrm{Pu}$ and americium (Am) contamination for National Emission Standards for Hazardous Air Pollutants (NESHAPs) compliance. The DRI samples were collected on Teflon membrane filters by portable low volume $(5 \mathrm{l} / \mathrm{min})$ samplers; the SNL samples were collected on quartz fiber filters by high-volume $\mathrm{PM}_{10}$ samplers $\left(1.13 \mathrm{~m}^{3} / \mathrm{min}\right)$. The DRI sampling site was $3 \mathrm{~km}$ northwest of Clean Slate 3; the SNL sampling site was $8 \mathrm{~km}$ west-northwest of Clean Slate 3 and approximately 2.7 times the distance from Clean Slate 3 as the DRI sampling site. Data on total mass concentration of $\mathrm{PM}_{10}$ particles $\left(\mu \mathrm{g} / \mathrm{m}^{3}\right)$, total radionuclide activity for $\mathrm{Pu}$ isotopes, and radionuclide activity concentration were compared with the DRI data representing the "near-field" set and the SNL data the "far-field" set.

The $\mathrm{PM}_{10}$ mass concentration for samples collected by SNL and by DRI averaged $6.2 \mu \mathrm{g} / \mathrm{m}^{3}$ and $6.9 \mu \mathrm{g} / \mathrm{m}^{3}$, respectively. Application of a Wilcoxon Rank-Sum test showed no statistical difference between the two sets of mass concentrations, which implies a relatively uniform aerosol loading in the area to the north of the Clean Slate sites. The similarity of the mass concentrations and their low values indicate that there were no major sources of airborne $\mathrm{PM}_{10}$ near either site, although simultaneous measurements upwind and downwind of the Clean Slate sites would have been necessary to definitively determine emissions that might have come from the Clean Slate sites. From the available data there is no indication that airborne $\mathrm{PM}_{10}$ particles are being transported farther to the SNL site. However, the data are statistically insufficient to conclude whether there is significant difference in transport of Pu particles in the $\mathrm{PM}_{10}$ size range in large part because of the small number of samples where the total activity or the activity concentration exceeded the Minimum Detection Activity (MDA). Only 20.8 percent of the SNL samples and only one of the four DRI composite samples for ${ }^{238} \mathrm{Pu}$ and ${ }^{239+240} \mathrm{Pu}$ exceeded the MDA. Comparisons of total radionuclide activity and activity concentration could only be conducted by substituting the MDA for samples for which levels were below detection. While the low values of total activity and activity concentration suggest that the inhalation hazard of $\mathrm{Pu}$ from the Clean Slate sites is low, the data are insufficient to conclude whether there is a difference in transport of respirable $\mathrm{Pu}$ particles to the near-field versus the far-field sites from the Clean Slate sites. 


\section{CONTENTS}

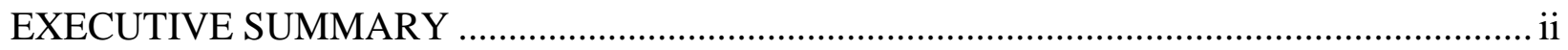

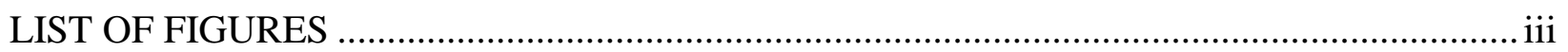

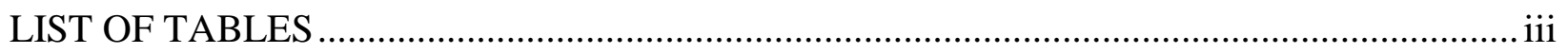

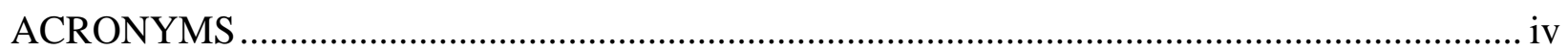

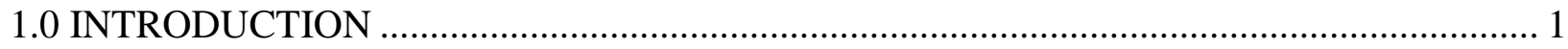

2.0 PARTICLE COLLECTION AND ANALYSES ................................................... 4

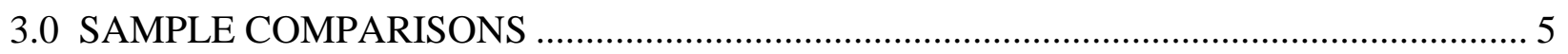

3.1 Mass Concentration Comparisons .........................................................................

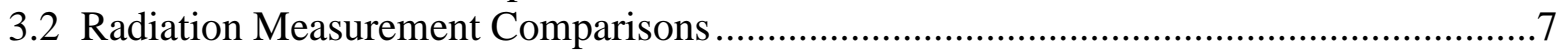

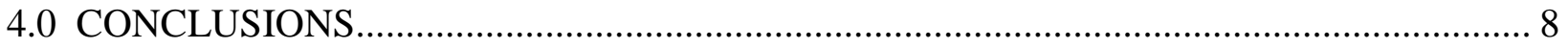

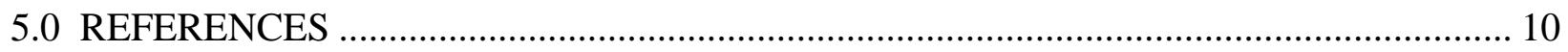

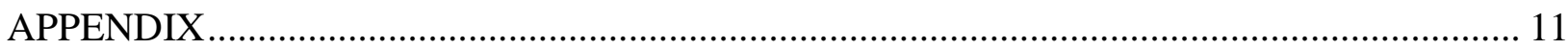

\section{LIST OF FIGURES}

1. U.S. Department of Energy, National Nuclear Security Administration sites and facilities in Nevada where environmental restoration is occurring, including the Tonopah Test Range. . 2

2. SNL and DRI sampling sites at the Tonopah Test Range. 3

\section{LIST OF TABLES}

1. Wind frequency in percent at the Clean Slate background site, Feb 1996 - Jan 1997........... 3

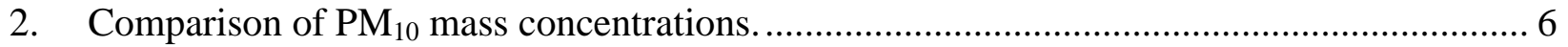

3. SNL samples compared to minimum detection activity. ............................................. 7

4. Maximum activities for three-month composite samples............................................ 9

A-1. Ambient Concentrations of Airborne $\mathrm{PM}_{10}$ at Clean Slate Background Site, TTR, 26 January 1996 to 29 April $1996^{\mathrm{a}}$................................................................................. 12

A-2. Ambient Concentrations of Airborne $\mathrm{PM}_{10}$ at Clean Slate Background Site, TTR, 3 May 1996 to 29 July $1996^{\mathrm{a}}$.

A-3. Ambient Concentrations of Airborne $\mathrm{PM}_{10}$ at Clean Slate Background Site, TTR, 2 August 1996 to 28 October $1996^{\mathrm{a}}$.

A-4. Ambient Concentrations of Airborne $\mathrm{PM}_{10}$ at Clean Slate Background Site, TTR, 1 November 1996 to 7 February $1997^{\mathrm{a}} .$. 


\section{ACRONYMS}

Am

$\mathrm{BN}$

DCG

DRI

EDE

MDA

MEI

NESHAPs

NNSA/NV

$\mathrm{Pu}$

SNL

TTR americium

Bechtel Nevada

Derived Concentration Guide

Desert Research Institute

effective dose equivalent

Minimum Detection Activity

Maximally Exposed Individual

National Emission Standards for Hazardous Air Pollutants

National Nuclear Security Administration/Nevada Operations Office plutonium

Sandia National Laboratories

Tonopah Test Range 


\subsection{INTRODUCTION}

Operation Roller Coaster was a series of nuclear material dispersal experiments, including three (Clean Slate 1, 2, and 3) that resulted in widespread areas of surface soil plutonium (Pu) contamination on the Tonopah Test Range (TTR) in Nevada. The Clean Slates 1, 2 , and 3 experiments resulted in the dispersal of $\mathrm{Pu}$ from nuclear devices over the area surrounding the three ground zeros as well as downwind. The TTR is located $225 \mathrm{~km}$ (140 miles) northwest of Las Vegas, Nevada, within the boundaries of the Nellis Air Force Range (Figure 1). U.S. Department of Energy's National Nuclear Security Administration (NNSA) operations at TTR are conducted by Sandia National Laboratories-New Mexico (SNL), although environmental restoration of the Clean Slate sites is being conducted by the NNSA Nevada Operations Office (NV).

As part of the Soils Project of the NNSA/NV Environmental Restoration Project, largescale surface excavation of surface soils has already been conducted at Clean Slate 1. To support the remediation of the Clean Slate sites, Desert Research Institute (DRI) collected samples of airborne particles prior to soil excavation to establish background dispersal of $\mathrm{Pu}$ from the sites for comparison with air monitoring data collected after excavation. The focus of background sampling was on particles with aerodynamic diameters less than $10 \mu \mathrm{m}\left(\mathrm{PM}_{10}\right)$, the particle size range of greatest health concern to site workers or potential off-site receptors from respiration. For ambient background measurements for the Clean Slate sites, portable PM $_{10}$ samplers were deployed $3 \mathrm{~km}$ to the west-northwest of Clean Slate 3 (Bowen, 1996a,b,c, 1997a). The locations of the sampling sites are displayed in Figure 2, as are the Clean Slate sites.

The State of Nevada, Division of Environmental Protection, has raised concerns to NNSA/NV that dispersal of $\mathrm{Pu}$ particles from the Clean Slate sites may result in deposition of $\mathrm{Pu}$ particles farther downwind where samplers deployed by DRI would not have detected them. To begin addressing this issue, NNSA/NV sought to make a comparison of existing air monitoring data that were collected at a greater distance ("far-field") from the Clean Slate sites than data collected by DRI as part of background monitoring ("near-field"). The data set selected for comparison was air-monitoring data collected by SNL as part of National Emission Standards for Hazardous Air Pollutants (NESHAPs) requirements for TTR (SNL, 1997). SNL was required under its NESHAPs permit for TTR to measure emissions of radionuclides from "diffuse" sources, namely the three Clean Slate sites. The period of SNL data collection virtually coincides with the one year of continuous background monitoring by DRI between February 1996 and January 1997 prior to excavation work on any of the Clean Slate sites (Bowen, 1997b).

Between February 1996 and February 1997, as part of a NESHAPs study to measure the dose of a Maximally Exposed Individual (MEI) at TTR, SNL conducted one year of continuous air monitoring near the Clean Slate sites (Culp et al., 1998). The MEI location near the airfield at TTR is about $8 \mathrm{~km}$ west-northwest of Clean Slate 3, and approximately 2.7 times the distance from Clean Slate 3 as the background sampling site used by DRI. Data on $\mathrm{PM}_{10}$ particle mass concentration $\left(\mu \mathrm{g} / \mathrm{m}^{3}\right)$, total activity for ${ }^{238} \mathrm{Pu}$ and ${ }^{239+240} \mathrm{Pu}(\mathrm{pCi})$, and radionuclide concentration ( $\mathrm{pCi} / \mathrm{g}$ ) for the $\mathrm{Pu}$ isotopes from these two data sets have been herein compared to evaluate whether there is evidence of farther afield transport (namely to the SNL MEI site) of Pu from the Clean Slate sites that is in addition to that detected at the near-field site.

On an annual basis, TTR has a dichotomy in prevailing wind directions. From late fall to the spring, winds are mostly from the northwest, being influenced by the Pacific air flow patterns 


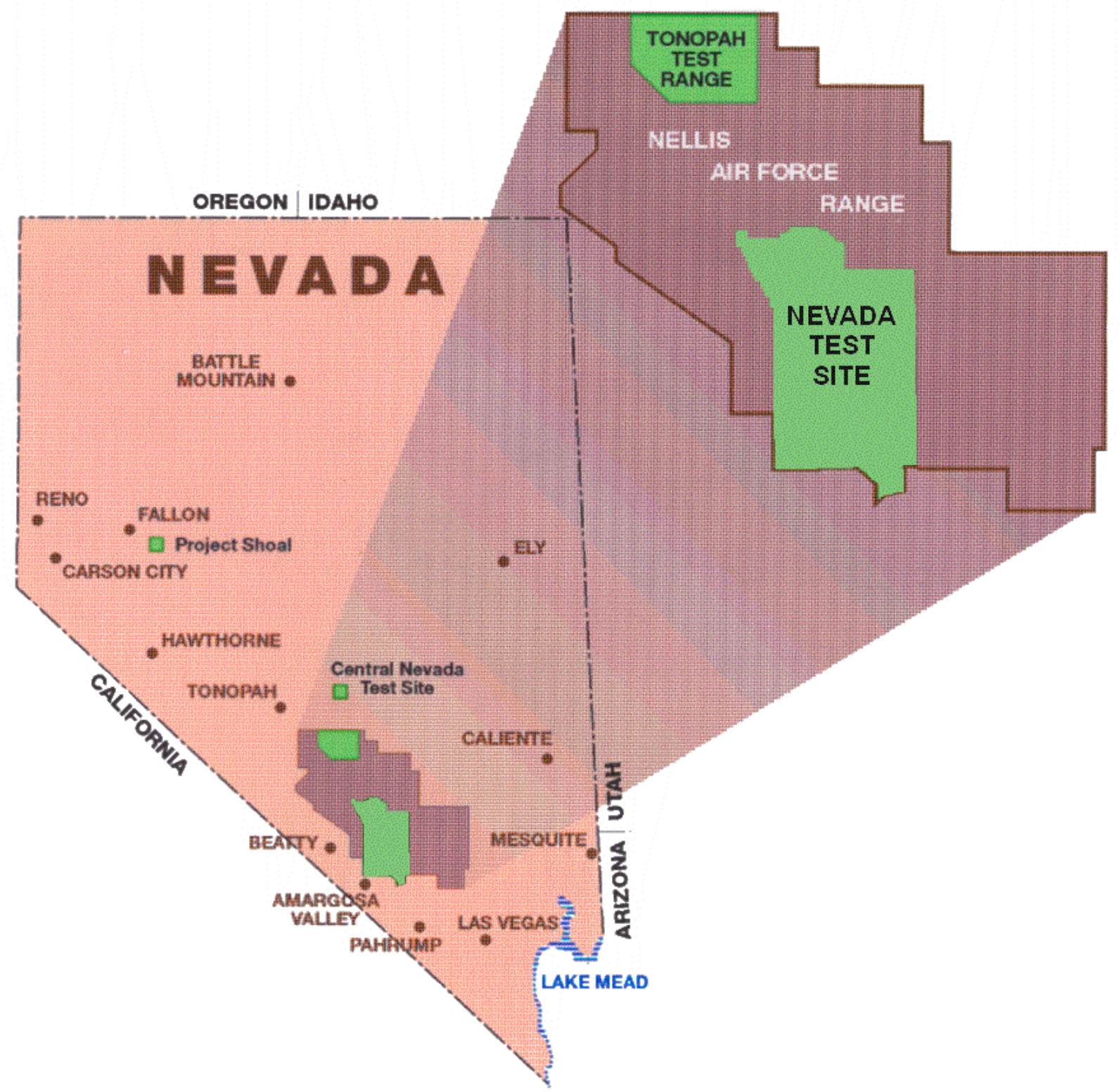

Figure 1. U.S. Department of Energy, National Nuclear Security Administration sites and facilities in Nevada where environmental restoration is occurring, including the Tonopah Test Range.

over the Sierra Nevada Mountains. From summer through early fall, the winds generally shift to a southeasterly direction from air masses moving out of the Gulf of Mexico and Gulf of California (Culp et al., 1998). The winds measured by DRI at the Clean Slate background site also showed this dichotomy in the prevailing directions for February 1996 through January 1997. As shown in Table 1, most of the directions were in the southerly sector from southeasterly to southwesterly or in the northerly sector from northwesterly to northeasterly. During the 12 months including the 11-month overlap period between sampling by DRI and SNL, the winds were southerly 45 percent of the time and northerly 37 percent of the time. The wind was calm 8 percent of the time and had directions other than southerly or northerly 10 percent of the time. As 


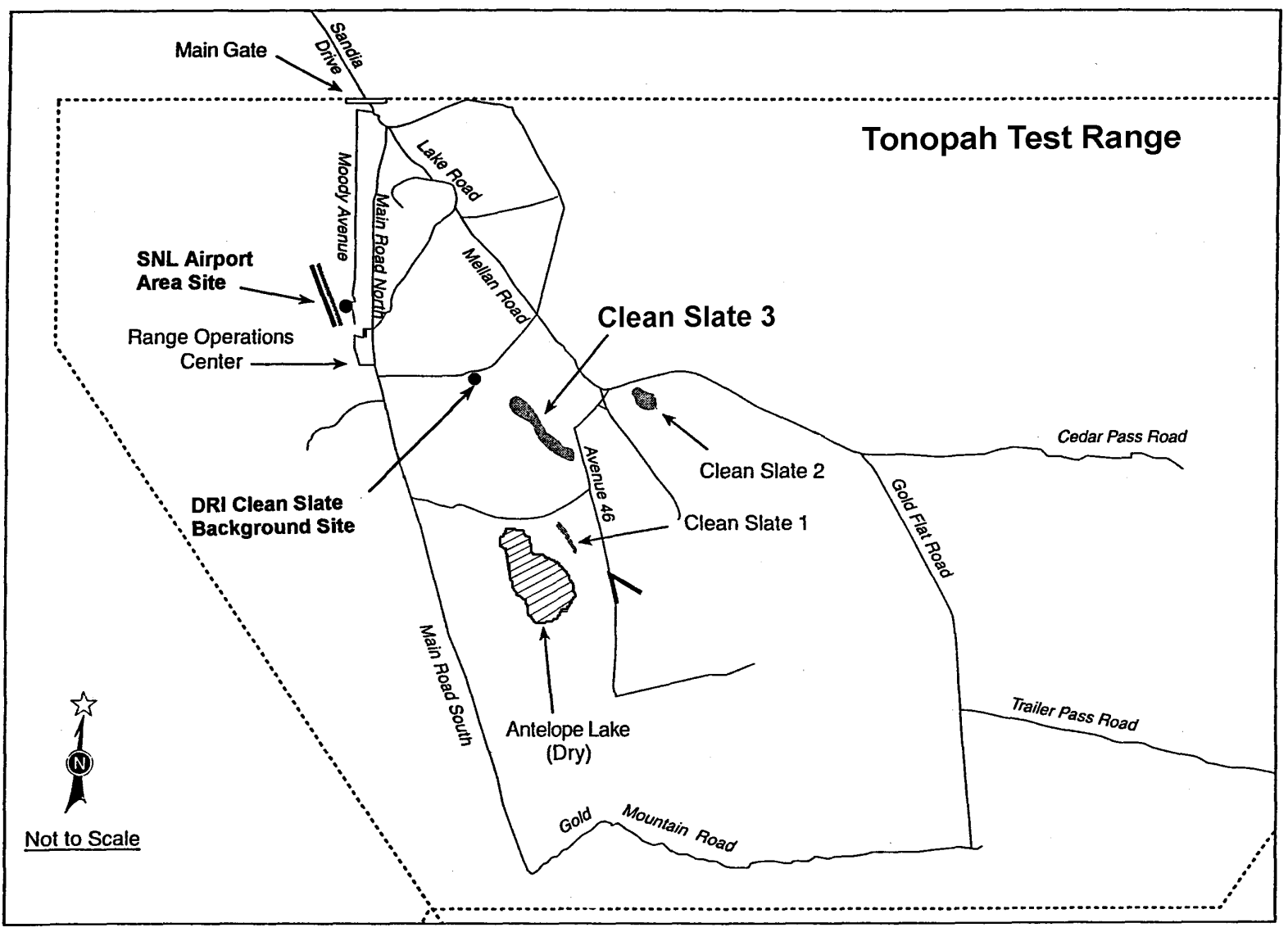

Figure 2. SNL and DRI sampling sites at the Tonopah Test Range.

Table 1. Wind frequency in percent at the Clean Slate background site, Feb 1996 - Jan 1997.

\begin{tabular}{||l|c|c|c|c|c|c|c|c|c||}
\hline \multirow{2}{*}{ Month } & \multicolumn{3}{|c|}{ Day } & \multicolumn{3}{c|}{ Night } & \multicolumn{3}{c||}{ Total } \\
\cline { 2 - 10 } & Northerly & Southerly & Calm & Northerly & Southerly & Calm & Northerly & Southerly & Calm \\
\hline \hline Feb 1996 & 34 & 49 & 7 & 34 & 46 & 13 & 34 & 47 & 11 \\
\hline Mar 1996 & 46 & 41 & 4 & 42 & 44 & 7 & 44 & 43 & 6 \\
\hline Apr 1996 & 59 & 26 & 6 & 57 & 31 & 6 & 58 & 29 & 6 \\
\hline May 1996 & 60 & 31 & 2 & 58 & 25 & 8 & 59 & 28 & 5 \\
\hline Jun 1996 & 22 & 65 & 4 & 30 & 49 & 8 & 25 & 58 & 6 \\
\hline Jul 1996 & 16 & 70 & 4 & 26 & 53 & 9 & 21 & 62 & 6 \\
\hline Aug 1996 & 25 & 61 & 6 & 20 & 42 & 14 & 23 & 52 & 10 \\
\hline Sep 1996 & 34 & 49 & 5 & 28 & 43 & 8 & 31 & 46 & 7 \\
\hline Oct 1996 & 50 & 39 & 5 & 35 & 47 & 10 & 41 & 44 & 8 \\
\hline Nov 1996 & 45 & 40 & 8 & 39 & 43 & 11 & 42 & 42 & 10 \\
\hline Dec 1996 & 31 & 54 & 6 & 26 & 48 & 16 & 28 & 50 & 13 \\
\hline Jan 1997 & 43 & 47 & 8 & 39 & 38 & 15 & 41 & 41 & 12 \\
\hline 12 months & 38 & 48 & 5 & 36 & 43 & 11 & 37 & 45 & 8 \\
\hline Overlap Period & 39 & 48 & 5 & 36 & 42 & 10 & 37 & 45 & 8 \\
\hline \hline
\end{tabular}


noted above, summer months had higher incidences of southerly winds. In addition, southerly winds were more prevalent than northerly during both the daytime and nighttime, although more so during the daytime during the summer.

The comparison of the Clean Slate background monitoring results with the SNL NESHAPs monitoring results should not in any way be construed as a re-evaluation of the SNL data for meeting its NESHAPs requirements. That is, the SNL data were not specifically collected for this air monitoring results comparison. Lastly, as a point of reference, the ambient background air monitoring conducted by DRI and the NESHAPs data were collected prior to Corrective Action at any of the Clean Slate sites. Excavation of contaminated surface soils for remediation of Clean Slate 1 was done from April to August 1997.

\subsection{PARTICLE COLLECTION AND ANALYSES}

The SNL samples were collected on quartz filters with a high-volume $\mathrm{PM}_{10}$ sampler. The sampler was operated at a flow rate of approximately $1.13 \mathrm{~m}^{3} / \mathrm{min}\left(40 \mathrm{ft}^{3} / \mathrm{min}\right)$ in accordance with the design of the size-selective inlet used to obtain $\mathrm{PM}_{10}$. Individual air samples were exposed for 48 hours and then composited as 14-day samples. The filters were weighed before and after sampling to obtain the net mass loading on the filters. For each two-week period, seven filters were composited and analyzed for ${ }^{241} \mathrm{Am},{ }^{238} \mathrm{Pu}$, and ${ }^{239+240} \mathrm{Pu}$ by alpha spectroscopy. The concentrations of ambient $\mathrm{PM}_{10}$ were calculated for each composite period from the net mass collected, the flow rate, and the exposure time. Each individual sample represented a volume of about $3,100 \mathrm{~m}^{3}$ and each composite about 22,000 $\mathrm{m}^{3}$. Approximately $0.1 \mathrm{~g}$ of material would have been collected during a two-week period if the mass concentration in the ambient air had been $5 \mu \mathrm{g} / \mathrm{m}^{3}$.

The DRI samples were collected on Teflon filters by battery-operated, low-volume samplers that operated at $5 \mathrm{l} / \mathrm{min}$ flow rates for 24-hour periods. Two 24-hour samples were collected each week: one on Monday and the other on Friday. An additional collocated sample was collected each Monday. Each filter was weighed at DRI's Reno laboratory before and after sampling to obtain its net mass loading. The concentration of ambient $\mathrm{PM}_{10}$ for each sample period was calculated from the net mass collected, the flow rate, and the exposure time. The concentration on those days with two collocated samples was the average of the two samples. All exposed filters, including the collocated samples, were submitted to Bechtel Nevada (BN) Analytical Services Laboratory in Mercury, Nevada, for analysis of ${ }^{238} \mathrm{Pu}$ and ${ }^{239+240} \mathrm{Pu}$ by alpha spectroscopy. BN combined the material on the filters into four sets, each covering a three-month period, and then analyzed the four composite sets. $\mathrm{BN}$ provided activity data in $\mu \mathrm{Ci}$ per composite sample for ${ }^{238} \mathrm{Pu}$ and ${ }^{239+240} \mathrm{Pu}$ with Minimum Detection Activities (MDAs) for each sample. The samples were not analyzed for ${ }^{241} \mathrm{Am}$. Each sample represented a sample volume of about $7.2 \mathrm{~m}^{3}$. Approximately $36 \mu \mathrm{g}$ of material would have been collected on a filter if the ambient concentration had been $5 \mu \mathrm{g} / \mathrm{m}^{3}$. The quarterly composite samples, which consisted of about 40 filters, would have contained about $1.4 \mathrm{mg}$ of material.

SNL analyzed a total of 26 composite samples that were collected between the end of February 1996 and end of February 1997. DRI collected samples on 101 days of a possible 107 days between the end of January 1996 and the end of January 1997. A total of 144 valid filter samples, including the collocated samples, was collected, all of which were composited for radioactivity analysis. Samples were invalidated because of sampler failures that resulted in no sample collection and filter handling problems that resulted in damaged filters. For the 
overlapping period of sampling from the end of February 1996 to the end of January 1997, SNL collected 24 composites, while DRI collected samples on 94 of a possible 99 sample days. Corresponding to the DRI three-month composites, there were five, six and a half, six and a half, and six SNL composites for the first, second, third, and fourth periods, respectively.

\subsection{SAMPLE COMPARISONS}

\subsection{Mass Concentration Comparisons}

The DRI mass concentrations for $\mathrm{PM}_{10}$ particles for each SNL sample period were identified and averaged for comparison to the SNL mass concentrations for those periods as shown in Table 2. The average concentrations were $6.2 \mu \mathrm{g} / \mathrm{m}^{3}$ for the SNL samples and 6.9 $\mu \mathrm{g} / \mathrm{m}^{3}$ for the DRI samples. The variation of the two sample sets was similar with the SNL samples having a standard deviation of $\pm 3.8 \mu \mathrm{g} / \mathrm{m}^{3}$ and a range of $0.4 \mu \mathrm{g} / \mathrm{m}^{3}$ to $14.9 \mu \mathrm{g} / \mathrm{m}^{3}$ and the DRI samples having a standard deviation of $\pm 4.1 \mu \mathrm{g} / \mathrm{m}^{3}$ and a range of $1.8 \mu \mathrm{g} / \mathrm{m}^{3}$ to 15.2 $\mu \mathrm{g} / \mathrm{m}^{3}$. The DRI mass concentrations were higher than their corresponding SNL concentrations for 14 samples, while SNL concentrations were higher for 10 samples. All of the DRI mass concentrations are included in the Appendix as well as the uncertainties of the mass concentration measurements. The uncertainties have been calculated using the method of Watson et al. (1989) in which variances of the collocated and blank filter measurements and of the collected volume are propagated to the measurements of the mass concentrations. The uncertainties have been determined for the three-month periods that corresponded to the original reporting periods, since the mass data were adjusted for the blank filter masses during those periods. The variances of the collocated mass differences and the blanks controlled the uncertainty for samples that were exposed for 24 hours so that the uncertainties for each three-month period were the same. For samples that were exposed for other than 24 hours, uncertainties changed in inverse proportion to the fraction of the day sampled. The uncertainties for the 24-hour samples were $3.4 \mu \mathrm{g} / \mathrm{m}^{3}$ for January to April 1996, $2.7 \mu \mathrm{g} / \mathrm{m}^{3}$ for May to July 1996, $3.3 \mu \mathrm{g} / \mathrm{m}^{3}$ for August to October 1996, and $1.3 \mu \mathrm{g} / \mathrm{m}^{3}$ for November 1996 to February 1997.

Although the two sample sets were collected during the same time period, they were not collected with the same type of instruments at the same frequency or at the same locations and were not truly paired samples. To compare the concentrations of the two sets of measurements, a nonparametric statistical test that allows the testing for the difference between the medians of two independent samples, the Wilcoxon Rank-Sum Test, was used (Computing Resource Center, 1992). This test did not require that the underlying distributions for the two sets of samples were normal but generated a statistic, the Wilcoxon Rank-Sum Statistic, that had an approximately normal distribution (Weinberg et al., 1981). The composite SNL data and the average DRI mass concentrations were combined into one set of data and ranked in ascending order with each concentration given a number rank. Equal concentrations were given equal to the average of the ranks for those concentrations. The Wilcoxon Rank-Sum Statistics for each sample were calculated as the sum of the ranks for each sample: 560.5 for the 24 SNL samples and 615.5 for the 24 DRI samples. The expected value for each statistic was found from

$$
E\left(T_{\text {SNLor DRI }}\right)=\frac{m_{\text {SNLor DRI }}(N+1)}{m_{\text {SNLor DRI }}}
$$


Table 2. Comparison of $\mathrm{PM}_{10}$ mass concentrations.

\begin{tabular}{|c|c|c|c|c|c|}
\hline \multicolumn{3}{|c|}{ SNL NESHAPs Sampling } & \multicolumn{3}{|c|}{ DRI Clean Slate Background Sampling } \\
\hline \multicolumn{2}{|c|}{ Composite } & \multirow{2}{*}{$\begin{array}{c}\text { Composite } \mathrm{PM}_{10} \\
\text { Concentration } \\
\left(\mu \mathrm{g} / \mathrm{m}^{3}\right) \\
\end{array}$} & \multicolumn{2}{|c|}{ Sample Dates } & \multirow{2}{*}{$\begin{array}{c}\text { Average } \mathrm{PM}_{10} \\
\text { Concentration } \\
\quad\left(\mu \mathrm{g} / \mathrm{m}^{3}\right)\end{array}$} \\
\hline Start & End & & First & Last & \\
\hline 02/20/1996 & $03 / 04 / 1996$ & 5.3 & $02 / 23 / 1996$ & $03 / 04 / 1996$ & 2.3 \\
\hline 03/05/1996 & $03 / 18 / 1996$ & 3.0 & $03 / 08 / 1996$ & $03 / 18 / 1996$ & 3.8 \\
\hline $03 / 19 / 1996$ & $04 / 01 / 1996$ & 6.1 & $03 / 22 / 1996$ & $04 / 01 / 1996$ & 7.1 \\
\hline $04 / 02 / 1996$ & $04 / 15 / 1996$ & 5.0 & $04 / 05 / 1996$ & $04 / 15 / 1996$ & 9.5 \\
\hline $04 / 16 / 1996$ & $04 / 29 / 1996$ & 6.9 & $04 / 19 / 1996$ & $04 / 29 / 1996$ & 8.1 \\
\hline $04 / 30 / 1996$ & 05/13/1996 & 6.3 & 05/03/1996 & $05 / 13 / 1996$ & 7.3 \\
\hline 05/14/1996 & $05 / 27 / 1996$ & 7.3 & $05 / 17 / 1996$ & $05 / 27 / 1996$ & 11.9 \\
\hline $05 / 28 / 1996$ & $06 / 10 / 1996$ & 10.1 & $05 / 31 / 1996$ & $06 / 10 / 1996$ & 14.6 \\
\hline $06 / 11 / 1996$ & $06 / 24 / 1996$ & 10.3 & $06 / 14 / 1996$ & $06 / 24 / 1996$ & 12.8 \\
\hline $06 / 25 / 1996$ & $07 / 06 / 1996$ & 6.7 & $06 / 28 / 1996$ & $07 / 08 / 1996$ & 9.5 \\
\hline $07 / 09 / 1996$ & $07 / 22 / 1996$ & 8.0 & $07 / 12 / 1996$ & $07 / 22 / 1996$ & 5.8 \\
\hline $07 / 23 / 1996$ & 08/09/1996 & 12.9 & $07 / 26 / 1996$ & 08/05/1996 & 15.2 \\
\hline 08/10/1996 & $08 / 23 / 1996$ & 14.9 & $08 / 12 / 1996$ & $08 / 23 / 1996$ & 11.4 \\
\hline $08 / 24 / 1996$ & $09 / 06 / 1996$ & 11.0 & $08 / 26 / 1996$ & $09 / 06 / 1996$ & 9.1 \\
\hline $09 / 07 / 1996$ & $09 / 20 / 1996$ & 6.5 & $09 / 09 / 1996$ & $09 / 20 / 1996$ & 6.4 \\
\hline 09/21/1996 & $10 / 06 / 1996$ & 7.1 & $09 / 23 / 1996$ & $10 / 04 / 1996$ & 5.6 \\
\hline $10 / 07 / 1996$ & $10 / 20 / 1996$ & 7.0 & $10 / 11 / 1996$ & $01 / 00 / 00$ & 5.2 \\
\hline $10 / 21 / 1996$ & $11 / 01 / 1996$ & 4.5 & $10 / 21 / 1996$ & $11 / 01 / 1996$ & 4.4 \\
\hline $11 / 02 / 1996$ & $11 / 17 / 1996$ & 3.0 & $11 / 04 / 1996$ & $11 / 15 / 1996$ & 1.8 \\
\hline $11 / 18 / 1996$ & $12 / 07 / 1996$ & 1.9 & $11 / 18 / 1996$ & $12 / 02 / 1996$ & 1.8 \\
\hline $12 / 08 / 1996$ & $12 / 21 / 1996$ & 1.4 & $12 / 09 / 1996$ & $12 / 20 / 1996$ & 4.5 \\
\hline $12 / 22 / 1996$ & 01/06/1997 & 1.0 & $12 / 23 / 1996$ & 01/06/1997 & 3.6 \\
\hline $01 / 07 / 1997$ & $01 / 20 / 1997$ & 1.6 & $01 / 10 / 1997$ & $01 / 20 / 1997$ & 1.9 \\
\hline $01 / 21 / 1997$ & $02 / 03 / 1997$ & 0.4 & $01 / 24 / 1997$ & $01 / 31 / 1997$ & 2.6 \\
\hline \multicolumn{2}{|c|}{ Average } & 6.2 & \multicolumn{2}{|c|}{ Average } & 6.9 \\
\hline \multicolumn{2}{|c|}{ Standard Deviation } & 3.8 & \multicolumn{2}{|c|}{ Standard Deviation } & 4.1 \\
\hline \multicolumn{2}{|c|}{ Maximum } & 14.9 & \multicolumn{2}{|c|}{ Maximum } & 15.2 \\
\hline \multicolumn{2}{|c|}{ Minimum } & 0.4 & \multicolumn{2}{|c|}{ Minimum } & 1.8 \\
\hline \multicolumn{2}{|c|}{ Number } & 24 & \multicolumn{2}{|c|}{ Number } & 24 \\
\hline \multicolumn{6}{|c|}{ Wilcoxon Rank-Sum Test } \\
\hline & & & \multicolumn{2}{|l|}{ SNL } & DRI \\
\hline \multicolumn{3}{|c|}{ Wilcoxon Rank-Sum Statistic } & \multicolumn{2}{|c|}{560.5} & 615.5 \\
\hline \multicolumn{3}{|c|}{ Expected Sum of Ranks } & \multicolumn{3}{|c|}{588} \\
\hline \multicolumn{3}{|c|}{ Variance } & \multicolumn{3}{|c|}{2352} \\
\hline \multicolumn{3}{|c|}{ Z-Statistic } & \multicolumn{2}{|c|}{-0.567} & 0.567 \\
\hline \multicolumn{3}{|c|}{ Probability of incorrectly rejecting null hypothesis } & & 0.571 & \\
\hline
\end{tabular}


where $\mathrm{E}\left(\mathrm{T}_{\mathrm{SNL}}\right.$ or DRI $)$ was the expected value for the ranks of either SNL or DRI concentrations, $\mathrm{m}_{\mathrm{SNL}}$ or DRI was the number of concentrations in the particular set of concentrations, and $\mathrm{N}$ was the total number of concentrations. The variance for either set of concentrations was given by

$$
\operatorname{Var}\left(T_{S N L \text { or DRI }}\right)=\frac{m_{S N L} m_{D R I}(N+1)}{12}
$$

where $\operatorname{Var}\left(\mathrm{T}_{\mathrm{SNL}}\right.$ or DRI $)$ was the variance of the ranks for either SNL or DRI concentrations and $m_{S N L}$ and $m_{D R I}$ were the number of concentrations for the two sets. For the data in question, the expected value for the sum of the ranks was 588 and the variance was 2,352.

The medians of the two distributions were compared with a statistical test that first assumed that there was no difference between the actual sums of ranks and the expected sum of ranks, i.e., the null hypothesis. The probability of incorrectly rejecting this null hypothesis gave a measure of the statistical significance of possible differences between the medians of the distributions of the concentrations. Since the distribution of the Wilcoxon Rank-Sum Statistics was approximately normal, the following $\mathrm{Z}$ statistic was generated for comparison with a normal distribution:

$$
Z_{S N L \text { or DRI }}=\frac{T_{S N L \text { or DRI }}-E\left(T_{\text {SNLor DRI }}\right)}{\sqrt{\operatorname{Var}\left(T_{\text {SNLor DRI }}\right)}}
$$

The $\mathrm{Z}$ statistics were -0.567 for the SNL ranks and 0.567 for the DRI ranks. For a twosided test of a normal distribution, these $\mathrm{Z}$ statistics showed that the medians were not statistically different at any level smaller than the 57.1 percent level. It can be concluded from this test that the calculated median mass loadings of $\mathrm{PM}_{10}$ particles at the two sites were not different.

\subsection{Radiation Measurement Comparisons}

Data listed in SNL's NESHAPs report and supplied to DRI by SNL show that the amount of radioactivity on most of the composite samples was at or below the MDAs of the measurement technique. Table 3 gives the number of SNL samples for the overlapping period with the DRI samples that had activities greater than, equal to, and less than the MDA.

Radiation measurements of the DRI samples showed activities that were below MDAs for three of the four composites. Only one sample had a ${ }^{239+240} \mathrm{Pu}$ activity that was above detection limits.

Table 3. SNL samples compared to minimum detection activity.

\begin{tabular}{||c|c|c|c|}
\hline \multirow{2}{*}{$\begin{array}{c}\text { Sample Activity Relative to Minimum } \\
\text { Detection Activity }\end{array}$} & \multicolumn{3}{|c|}{ Number of Samples } \\
\cline { 2 - 4 } & ${ }^{241} \mathrm{Am}$ & ${ }^{238} \mathrm{Pu}$ & ${ }^{239+240} \mathrm{Pu}$ \\
\hline \hline Sample Activity > MDA & 5 & 1 & 6 \\
\hline Sample Activity = MDA & 4 & 1 & 16 \\
\hline Sample Activity < MDA & 15 & 22 & 2 \\
\hline
\end{tabular}


With most of the measurements below detection limits, the activities of the two sets of samples cannot be definitively compared. The activities could only be compared by replacing those activities that were below detection limits with their MDAs.

To compare maximum possible sample activities, the SNL activities were combined into four groups with each corresponding to one of the DRI composite periods. The activities of the combined SNL samples were computed as total activity in $\mathrm{pCi} / \mathrm{g}$ and activity concentrations in $\mathrm{pCi} / \mathrm{m}^{3}$ with the MDAs used for those samples having activities below the MDA. The SNL and DRI activities for the three-month periods are given in Table 4. The one DRI sample that was above detection limits is noted in the table. The number of SNL samples at or above detection limits is also noted for each three-month period.

The total activities on the SNL samples were higher than those on the DRI samples, likely the result of collecting a much higher amount of mass with the higher volume air samplers and longer exposure times used for the NESHAPs monitoring. However, the activity concentration, in $\mathrm{pCi} / \mathrm{g}$, was greater for the one DRI composite sample above the MDA. The SNL samples for the February-April 1996 and May-July 1996 periods, most of which were at or above the MDAs for ${ }^{241} \mathrm{Am}$ and ${ }^{239+240} \mathrm{Pu}$, had activity concentrations that were a few tenths of a $\mathrm{pCi} / \mathrm{g}$, while the DRI activity was $77 \mathrm{pCi} / \mathrm{g}$ for ${ }^{239+240} \mathrm{Pu}$ for the February-April 1996 composite. DRI samples for the August-October 1996 period had lower MDAs and thus lower possible maximum activities than during the two previous periods but still had MDAs that were five times the maximum possible SNL MDAs. The SNL samples for November 1996-January 1997 had higher MDAs than in previous months but still had maximum possible activities that were half those of the maximum possible DRI activities. However, the limited number of samples exceeding the MDA limits the significance of these seasonal differences.

\subsection{CONCLUSIONS}

The $\mathrm{PM}_{10}$ mass concentrations for samples collected by SNL at a site near the TTR airport and by DRI at the Clean Slate background site averaged $6.2 \mu \mathrm{g} / \mathrm{m}^{3}$ and $6.9 \mu \mathrm{g} / \mathrm{m}^{3}$, respectively, for the comparison period. Application of a Wilcoxon Rank-Sum Test showed that there was no statistical difference between the medians of the mass concentrations of the two sample sets, which implies a relatively uniform aerosol loading in the area to the north of the Clean Slate sites. The similar mass concentrations and their low values imply that there were no major sources of airborne $\mathrm{PM}_{10}$ near either sampling site, although simultaneous measurements upwind and downwind of the Clean Slate sites would have been necessary to definitively determine emissions that might have come from the Clean Slate sites. More specifically, there is no indication from the available data that airborne $\mathrm{PM}_{10}$ particles are being transported farther to the SNL NESHAPs monitoring location from the Clean Slate sites than to the near-field, DRI monitoring site.

However, the available data are insufficient to conclude whether there are significant differences in the transport of airborne plutonium particles in the respirable size range between the near-field (DRI) and the far-field (SNL) monitoring sites. In large part, this is a consequence of the small number of samples where the total activity or the activity concentration exceeded the MDA of the measurements. Only 10 of 48 SNL samples (20.8 percent) had activities for ${ }^{238} \mathrm{Pu}$ and ${ }^{239+240} \mathrm{Pu}$ that were equal to or greater than the MDA. Similarly, only one of the four composite samples collected by DRI had a ${ }^{239+240} \mathrm{Pu}$ activity that exceeded the MDA. The low 
Table 4. Maximum activities for three-month composite samples.

\begin{tabular}{|c|c|c|c|c|c|c|c|c|c|c|c|c|c|}
\hline \multirow{2}{*}{ Organization } & \multicolumn{4}{|c|}{ Composite } & \multicolumn{3}{|c|}{$\begin{array}{c}\text { Maximum } \\
\text { Activity/Composite, } \mathrm{pCi} \\
\end{array}$} & \multicolumn{3}{|c|}{$\begin{array}{l}\text { Maximum Activity/Composite, } \\
\mathrm{pCi} / \mathrm{m}^{3}\end{array}$} & \multicolumn{3}{|c|}{$\begin{array}{c}\text { Maximum } \\
\text { Activity/Composite, } \mathrm{pCi} / \mathrm{g}\end{array}$} \\
\hline & Start & End & $\begin{array}{l}\text { Volume } \\
\mathrm{m}^{3}\end{array}$ & $\begin{array}{l}\text { Mass } \\
\mathrm{mg}\end{array}$ & ${ }^{241} \mathrm{Am}$ & ${ }^{238} \mathrm{Pu}$ & ${ }^{239+240} \mathrm{Pu}$ & ${ }^{241} \mathrm{Am}$ & ${ }^{238} \mathrm{Pu}$ & ${ }^{239+240} \mathrm{Pu}$ & ${ }^{241} \mathrm{Am}$ & ${ }^{238} \mathrm{Pu}$ & ${ }^{239+240} \mathrm{Pu}$ \\
\hline \multirow{4}{*}{$\mathrm{SNL}^{\mathrm{a}}$} & 02/20/1996 & 04/29/1996 & 105612.3 & 554.9 & 0.09 & 0.05 & 0.05 & $8.52 \mathrm{E}-07$ & $4.73 \mathrm{E}-07$ & $4.73 \mathrm{E}-07$ & 0.16 & 0.09 & 0.09 \\
\hline & $04 / 30 / 1996$ & 08/09/1996 & 146416.8 & 1301.1 & 0.13 & 0.29 & 0.09 & 8.88E-07 & $1.98 \mathrm{E}-06$ & $6.15 \mathrm{E}-07$ & 0.10 & 0.22 & 0.07 \\
\hline & 08/10/1996 & $11 / 01 / 1996$ & 118821.4 & 1023.6 & 0.75 & 1.01 & 1.02 & $6.31 \mathrm{E}-06$ & $8.50 \mathrm{E}-06$ & 8.58E-06 & 0.73 & 0.99 & 1.00 \\
\hline & $11 / 02 / 1996$ & 02/03/1997 & 190186.8 & 291.4 & 3.10 & 1.18 & 1.91 & $1.63 \mathrm{E}-05$ & $6.20 \mathrm{E}-06$ & $1.00 \mathrm{E}-05$ & 10.64 & 4.05 & 6.55 \\
\hline & & & & & & & & & & & & & \\
\hline \multirow{4}{*}{$\mathrm{DRI}^{\mathrm{b}}$} & 01/26/1996 & 04/29/1996 & 278.45 & 1.45 & - & 0.05 & $0.11^{\mathrm{b}}$ & - & $1.62 \mathrm{E}-04$ & $4.02 \mathrm{E}-04^{\mathrm{b}}$ & - & 31.0 & $77.2^{\mathrm{b}}$ \\
\hline & 05/03/1996 & 07/29/1996 & 249.55 & 2.69 & - & 0.05 & 0.05 & - & $1.92 \mathrm{E}-04$ & $1.92 \mathrm{E}-04$ & - & 17.8 & 17.8 \\
\hline & 08/02/1996 & $10 / 28 / 1996$ & 252.43 & 2.18 & - & 0.01 & 0.01 & - & $4.75 \mathrm{E}-05$ & $4.75 \mathrm{E}-05$ & - & 5.5 & 5.5 \\
\hline & $11 / 01 / 1996$ & 01/31/1997 & 244.23 & 0.83 & - & 0.01 & 0.01 & - & $4.09 \mathrm{E}-05$ & $4.09 \mathrm{E}-05$ & - & 12.0 & 12.0 \\
\hline
\end{tabular}

${ }^{a}$ SNL samples at or above detection limits in summation of composites:

Sample 1: 4 for ${ }^{241} \mathrm{Am}, 0$ for ${ }^{238} \mathrm{Pu}, 5$ for ${ }^{239+240} \mathrm{Pu}$ from a total of 5 samples

Sample 2: 2 for ${ }^{241} \mathrm{Am}, 1$ for ${ }^{238} \mathrm{Pu}, 3$ for ${ }^{239+240} \mathrm{Pu}$ from a total of 7 samples

Sample 3: 1 for ${ }^{241} \mathrm{Am}, 0$ for ${ }^{238} \mathrm{Pu}$, and 0 for ${ }^{239+240} \mathrm{Pu}$ from a total of 6 samples

Sample 4: 2 for ${ }^{241} \mathrm{Am}, 1$ for ${ }^{238} \mathrm{Pu}, 0$ for ${ }^{239+240} \mathrm{Pu}$ from a total of 6 samples

${ }^{\mathrm{b}}$ Analysis above detection limits 
values of total activity and activity concentration from both sites suggest the inhalation hazard from plutonium is low. Compared to the Derived Concentration Guide (DCG) for exposure to the general public of $3 \times 10^{-15} \mu \mathrm{Ci} / \mathrm{ml}$ (an effective dose equivalent \{EDE\} of $10 \mathrm{mrem} / \mathrm{yr}$ ), the highest measured concentration from the DRI sampling (the February to April 1996 sample) was 13.3 percent of the DCG (Bowen, 1997a). Similarly, SNL calculated average net activity concentrations from ${ }^{241} \mathrm{Am},{ }^{238} \mathrm{Pu}$, and ${ }^{239+240} \mathrm{Pu}$ for an EDE of $0.024 \mathrm{mrem} / \mathrm{yr}$, or 0.24 percent of the DCG of $10 \mathrm{mrem} / \mathrm{yr}$ (Sandia National Laboratories, 1997). Nevertheless, the data sets are statistically insufficient to conclude whether there are differences in transport of radionuclides from the Clean Slate sites to the near-field versus the far-field site.

\subsection{REFERENCES}

Bowen, J.L., 1996a. Ambient Airborne Particulate Matter and Meteorological Data, Double Tracks, Tonopah Test Range. January-April 1996. DRI Document Number 6355-6835560.3D1. Prepared for U.S. Department of Energy, Nevada Field Office, Las Vegas, Nevada, August 9, 1996.

Bowen, J.L., 1996b. Ambient Airborne Particulate Matter and Meteorological Data, Clean Slate, Tonopah Test Range, May-July 1996. DRI Document Number 6355-683-5560.2D1. Prepared for U.S. Department of Energy, Nevada Field Office, Las Vegas, Nevada, September 4, 1996.

Bowen, J.L., 1996c. Ambient Airborne Particulate Matter and Meteorological Data, Clean Slate, Tonopah Test Range, August-October 1996. DRI Document Number 6357-683-7560.3D1. Prepared for U.S. Department of Energy, Nevada Field Office, Las Vegas, Nevada, December 31, 1996.

Bowen, J.L., 1997a. Ambient Airborne Particulate Matter and Meteorological Data, Clean Slate, Tonopah Test Range, November 1996-January 1997. DRI Document Number 6355-6835560.2D1. Prepared for U.S. Department of Energy, Nevada Field Office, Las Vegas, Nevada, April 7, 1997.

Bowen, J.L., 1997b. Analysis of Ambient Airborne Particulate Matter for Plutonium, Clean Slate Background Samples, Tonopah Test Range, February, 1996 to January, 1997. DRI Document Number 6357-683-7560.4D1. Prepared for U.S. Department of Energy, Nevada Field Office, Las Vegas, Nevada, August 1, 1997.

Computing Resource Center, 1992. Stata Reference Manual: Release 3. $5^{\text {th }}$ ed., Santa Monica, CA, pp. 167-171.

Culp, T., W. Forston, D. Duncan and R. Sanchez, 1998. 1997 Annual Site Environmental Report, Tonopah Test Range. Sandia National Laboratories, SAND98-1832.

Sandia National Laboratories, 1997. Results of Continuous Air Monitoring at the Tonopah Test Range: from February 20, 1996 to February 25, 1997.

Watson, J.G., P.J. Lioy and P.K. Mueller, 1989. The Measurement Process: Precision, Accuracy, and Validity. In Air Sampling Instruments for Evaluation of Atmospheric Contaminants, (7th Ed.), S.V. Hering, ed., American Conference of Governmental Industrial Hygienists, Cincinnati, OH, pp. 51-57.

Weinberg, G.H., J.A. Schumaker and D. Oltman, 1981. Statistics: An Intuitive Approach. $4^{\text {th }}$ Ed. Brooks/Cole Publishing Co., Monterey, CA, pp. 409-413. 


\begin{abstract}
APPENDIX
Ambient Concentrations of Airborne $\mathrm{PM}_{10}$ at Clean Slate Background Site 26 January 1996 to 31 January 1997
\end{abstract}


Table A-1. Ambient Concentrations of Airborne PM $_{10}$ at Clean Slate Background Site, TTR, 26 January 1996 to 29 April 1996 .

\begin{tabular}{|c|c|c|c|c|c|c|}
\hline \multirow{2}{*}{ Filter ID } & \multirow{2}{*}{$\begin{array}{l}\text { Sampling } \\
\text { Date }\end{array}$} & Samp & Period & \multirow{2}{*}{$\begin{array}{c}\text { Sample day } \\
\text { Concentration }^{\mathrm{b}} \\
\mu \mathrm{g} / \mathrm{m}^{3}\end{array}$} & \multirow{2}{*}{$\begin{array}{c}\text { Collocated } \\
\text { Filter Concentration } \\
\mu \mathrm{g} / \mathrm{m}^{3}\end{array}$} & \multirow{2}{*}{ Comments } \\
\hline & & \multicolumn{2}{|c|}{ HHMM to HHMM } & & & \\
\hline CSTT001 & $1 / 26 / 1996$ & 0000 & 1914 & - & - & Weighing error \\
\hline CSTT003 & \multirow{2}{*}{$1 / 29 / 1996$} & 0000 & 2400 & \multirow{2}{*}{3.1} & 4.2 & \\
\hline CSTT004 $^{\mathrm{c}}$ & & 0000 & 2400 & & 2.0 & \\
\hline CSTT005 & $2 / 2 / 1996$ & 0000 & 2400 & 1.5 & - & \\
\hline CSTT007 & \multirow{2}{*}{ 2/5/1996 } & 0000 & 1944 & \multirow{2}{*}{3.8} & 3.9 & Short sample/ Pump stopped after 19.75 hours \\
\hline CSTT008 $^{\mathrm{c}}$ & & 0000 & 2400 & & 3.6 & \\
\hline CSTT009 & $2 / 9 / 1996$ & 0000 & 2400 & 4.2 & - & \\
\hline CSTT011 & \multirow{2}{*}{ 2/12/1996 } & 0000 & 2400 & \multirow{2}{*}{2.6} & 4.0 & \\
\hline $\mathrm{CSTT012}^{\mathrm{c}}$ & & 0000 & 2400 & & 1.1 & \\
\hline CSTT013 & $2 / 16 / 1996$ & 0000 & 2400 & 6.4 & - & \\
\hline CSTT015 & \multirow{2}{*}{ 2/19/1996 } & 0000 & 2400 & \multirow{2}{*}{6.5} & 7.4 & \\
\hline CSTT016 $^{\mathrm{c}}$ & & 0000 & 2400 & & 5.7 & \\
\hline CSTT017 & $2 / 23 / 1996$ & 0000 & 2353 & 3.2 & - & \\
\hline CSTT019 & \multirow{2}{*}{ 2/26/1996 } & 0000 & 2400 & \multirow[b]{2}{*}{ - } & \multirow{2}{*}{ - } & Weighting error \\
\hline CSTT020 $^{\mathrm{c}}$ & & 0000 & 2400 & & & Weighting error \\
\hline CSTT021 & $3 / 1 / 1996$ & 0000 & 0645 & 2.5 & - & Short sample/ Pump stopped after 6.75 hours \\
\hline CSTT023 & \multirow{2}{*}{ 3/4/1996 } & 0000 & 2400 & \multirow{2}{*}{3.5} & 5.6 & Estimated Time, No Elapsed Time Indicator \\
\hline CSTT024 $^{\mathrm{c}}$ & & 0000 & 2400 & & 1.4 & \\
\hline CSTT025 & $3 / 8 / 1996$ & 0000 & 2400 & 2.4 & - & \\
\hline CSTT027 & \multirow{2}{*}{$3 / 11 / 1996$} & 0000 & 2400 & \multirow{2}{*}{3.8} & 4.2 & Estimated Time, No Elapsed Time Indicator \\
\hline $\mathrm{CSTT}^{2} 28^{\mathrm{c}}$ & & 0000 & 2400 & & 3.3 & \\
\hline CSTT029 & $3 / 15 / 1996$ & 0000 & 2400 & 4.3 & - & \\
\hline CSTT031 & \multirow{2}{*}{$3 / 18 / 1996$} & 0000 & 2400 & \multirow{2}{*}{4.6} & 4.2 & \\
\hline $\mathrm{CSTT}^{2} 32^{\mathrm{c}}$ & & 0000 & 2400 & & 5.0 & \\
\hline CSTT033 & $3 / 22 / 1996$ & 0000 & 2400 & 8.1 & - & \\
\hline
\end{tabular}


Table A-1. Ambient Concentrations of Airborne PM $_{10}$ at Clean Slate Background Site, TTR, 26 January 1996 to 29 April $1996^{\mathrm{a}}$ (continued).

\begin{tabular}{|c|c|c|c|c|c|c|}
\hline \multirow{2}{*}{ Filter ID } & \multirow{2}{*}{$\begin{array}{c}\text { Sampling } \\
\text { Date }\end{array}$} & \multicolumn{2}{|c|}{ Sampling Period } & \multirow{2}{*}{$\begin{array}{c}\text { Sample day } \\
\text { Concentration } \\
\mu \mathrm{g} / \mathrm{m}^{3}\end{array}$} & \multirow{2}{*}{$\begin{array}{c}\text { Collocated } \\
\text { Filter Concentration } \\
\mu \mathrm{g} / \mathrm{m}^{3}\end{array}$} & \multirow{2}{*}{ Comments } \\
\hline & & \multicolumn{2}{|c|}{ HHMM to HHMM } & & & \\
\hline CSTT035 & \multirow{2}{*}{$3 / 25 / 1996$} & 0000 & 2400 & \multirow{2}{*}{2.9} & \multirow{2}{*}{$\begin{array}{l}2.6 \\
3.2\end{array}$} & \\
\hline CSTT036 $^{\mathrm{c}}$ & & 0000 & 2400 & & & \\
\hline CSTT039 & $3 / 29 / 1996$ & 0000 & 2400 & 10.8 & - & \\
\hline CSTT037 & \multirow{2}{*}{$4 / 1 / 1996$} & 0000 & 2400 & \multirow{2}{*}{6.5} & \multirow{2}{*}{$\begin{array}{l}3.8 \\
9.3\end{array}$} & \\
\hline $\mathrm{CSTT}^{\mathrm{C}} 38^{\mathrm{c}}$ & & 0000 & 0647 & & & Short sample/ Pump stopped after 6.75 hours \\
\hline CSTT041 & $4 / 5 / 1996$ & 0000 & 2400 & 4.7 & - & \\
\hline CSTT043 & \multirow{2}{*}{$4 / 8 / 1996$} & 0000 & 2115 & \multirow{2}{*}{7.7} & \multirow{2}{*}{$\begin{array}{l}6.3 \\
9.1\end{array}$} & Short sample/ Pump stopped after 21.25 hours \\
\hline CSTT044 $^{\mathrm{c}}$ & & 0000 & 1838 & & & Short sample/ Pump stopped after 18.5 hours \\
\hline CSTT045 & $4 / 12 / 1996$ & 0000 & 1708 & 25.4 & & Short sample/ Pump stopped after 17 hours \\
\hline CSTT047 & \multirow{2}{*}{$4 / 15 / 1996$} & 0000 & 2400 & \multirow[t]{2}{*}{ 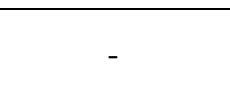 } & \multirow{2}{*}{ - } & Weighing error \\
\hline $\mathrm{CSTT}^{\mathrm{C}} 48^{\mathrm{c}}$ & & 0000 & 0000 & & & Pump did not start \\
\hline CSTT049 & $4 / 19 / 1996$ & 0000 & 2400 & 9.3 & & \\
\hline CSTT051 & \multirow{2}{*}{ 4/22/1996 } & 0000 & 2400 & \multirow{2}{*}{12.2} & \multirow{2}{*}{$\begin{array}{l}12.6 \\
11.8\end{array}$} & \\
\hline CSTT053 $^{\mathrm{c}}$ & & 0000 & 2400 & & & \\
\hline DTTT209 & $4 / 26 / 1996$ & 0000 & 2400 & 4.9 & & \\
\hline DTTT211 & \multirow{2}{*}{$4 / 29 / 1996$} & 0000 & 2400 & \multirow{2}{*}{5.9} & 8.3 & \\
\hline \multirow[t]{6}{*}{${\text { DTTT2 } 212^{\mathrm{c}}}^{\mathrm{c}}$} & & 0000 & 2113 & & 3.5 & Short sample/ Pump stopped after 21.25 hours \\
\hline & & \multicolumn{2}{|c|}{ Average } & 6.0 & & \\
\hline & & \multicolumn{2}{|c|}{ Std. Dev. } & 4.9 & & \\
\hline & & \multicolumn{2}{|c|}{ Maximum } & 25.4 & & \\
\hline & & \multicolumn{2}{|c|}{ Minimum } & 1.5 & & \\
\hline & & \multicolumn{2}{|c|}{ Number } & 25 & & \\
\hline
\end{tabular}

${ }^{a}$ For period, uncertainty for sample is $3.4 \times\left(1440 /\right.$ minutes of exposure) $\mu \mathrm{g} / \mathrm{m}^{3}$

b Sample day concentration from either single sample or from average of collocated concentrations

c Collocated sample 
Table A-2. Ambient Concentrations of Airborne $\mathrm{PM}_{10}$ at Clean Slate Background Site, TTR, 3 May 1996 to 29 July $1996^{\mathrm{a}}$.

\begin{tabular}{|c|c|c|c|c|c|c|}
\hline \multirow{2}{*}{ Filter ID } & \multirow{2}{*}{$\begin{array}{c}\text { Sampling } \\
\text { Date }\end{array}$} & \multicolumn{2}{|c|}{ Sampling Period } & \multirow{2}{*}{$\begin{array}{c}\text { Sample day } \\
\text { Concentration }^{\mathrm{b}} \\
\mu \mathrm{g} / \mathrm{m}^{3}\end{array}$} & \multirow{2}{*}{$\begin{array}{c}\text { Collocated } \\
\text { Filter Concentration } \\
\mu \mathrm{g} / \mathrm{m}^{3}\end{array}$} & \multirow{2}{*}{ Comments } \\
\hline & & \multicolumn{2}{|c|}{ HHMM to HHMM } & & & \\
\hline CSTT058 & $5 / 3 / 1996$ & 0000 & 2400 & 6.8 & - & \\
\hline CSTT060 & \multirow{2}{*}{$5 / 6 / 1996$} & 0000 & 2400 & \multirow{2}{*}{2.9} & 2.4 & \\
\hline CSTT061 $^{c}$ & & 0000 & 2400 & & 3.4 & \\
\hline CSTT062 & $5 / 10 / 1996$ & 0000 & 2400 & 9.2 & - & \\
\hline CSTT064 & \multirow{2}{*}{$5 / 13 / 1996$} & 0000 & 2400 & \multirow{2}{*}{10.4} & 9.3 & \\
\hline CSTT065 $^{\mathrm{c}}$ & & 0000 & 2400 & & 11.4 & \\
\hline CSTT066 & $5 / 17 / 1996$ & 0000 & 1208 & 17.3 & - & Short sample/ Pump stopped after 12 hours \\
\hline CSTT068 & \multirow{2}{*}{$5 / 20 / 1996$} & 0000 & 2400 & \multirow{2}{*}{12.0} & 13.1 & \\
\hline CSTT069 $^{c}$ & & 0000 & 2400 & & 11.0 & \\
\hline CSTT070 & $5 / 24 / 1996$ & 0000 & 2400 & 12.9 & - & \\
\hline CSTT072 & \multirow{2}{*}{$5 / 27 / 1996$} & 0000 & 2400 & \multirow{2}{*}{8.1} & \multirow{2}{*}{$\begin{array}{c}- \\
8.1\end{array}$} & Weighing error \\
\hline CSTT073 $^{c}$ & & 0000 & 2400 & & & \\
\hline CSTT074 & $5 / 31 / 1996$ & 0000 & 2400 & 18.5 & - & \\
\hline CSTT076 & \multirow{2}{*}{ 6/3/1996 } & 0000 & 2400 & \multirow{2}{*}{8.8} & 9.5 & \\
\hline $\mathrm{CSTT}^{2} 77^{\mathrm{C}}$ & & 0000 & 2400 & & 8.1 & \\
\hline CSTT078 & $6 / 7 / 1996$ & 0000 & 1128 & 30.9 & - & Short sample/ Pump stopped after 11.5 hours \\
\hline CSTT080 & \multirow{2}{*}{ 6/10/1996 } & 0000 & 2400 & \multirow{2}{*}{8.6} & 9.2 & \\
\hline CSTT081 $^{\mathrm{c}}$ & & 0000 & 2400 & & 8.1 & \\
\hline CSTT082 & $6 / 14 / 1996$ & 0000 & 2400 & 13.7 & - & \\
\hline CSTT084 & \multirow{2}{*}{$6 / 17 / 1996$} & 0000 & 2400 & \multirow{2}{*}{9.1} & 8.9 & \\
\hline CSTT085 $^{\mathrm{c}}$ & & 0000 & 2400 & & 9.3 & \\
\hline CSTT086 & $6 / 21 / 1996$ & 0000 & 2400 & 12.8 & - & \\
\hline CSTT088 & \multirow{2}{*}{$6 / 24 / 1996$} & 0000 & 2400 & \multirow{2}{*}{15.6} & 14.9 & \\
\hline CSTT089 $^{c}$ & & 0000 & 2400 & & 16.3 & \\
\hline CSTT090 & $6 / 28 / 1996$ & 0000 & 2400 & 6.1 & - & \\
\hline
\end{tabular}


Table A-2. Ambient Concentrations of Airborne $\mathrm{PM}_{10}$ at Clean Slate Background Site, TTR, 3 May 1996 to 29 July $1996^{\mathrm{a}}$ (continued).

\begin{tabular}{|c|c|c|c|c|c|c|}
\hline \multirow{2}{*}{ Filter ID } & \multirow{2}{*}{$\begin{array}{l}\text { Sampling } \\
\text { Date }\end{array}$} & \multicolumn{2}{|c|}{ Sampling Period } & \multirow{2}{*}{$\begin{array}{c}\text { Sample day } \\
\text { Concentration }^{\mathrm{b}} \\
\mu \mathrm{g} / \mathrm{m}^{3}\end{array}$} & \multirow{2}{*}{$\begin{array}{c}\text { Collocated } \\
\text { Filter Concentration } \\
\mu \mathrm{g} / \mathrm{m}^{3} \\
\end{array}$} & \multirow{2}{*}{ Comments } \\
\hline & & \multicolumn{2}{|c|}{ HHMM to HHMM } & & & \\
\hline CSTT092 & \multirow{2}{*}{ 7/1/1996 } & 0000 & 2400 & \multirow{2}{*}{10.5} & \multirow{2}{*}{$\begin{array}{c}9.5 \\
11.6\end{array}$} & \\
\hline CSTT093 $^{\mathrm{c}}$ & & 0000 & 2400 & & & \\
\hline CSTT094 & $7 / 5 / 1996$ & 0000 & 2400 & 7.7 & - & \\
\hline CSTT096 & \multirow{2}{*}{$7 / 8 / 1996$} & 0000 & 2400 & \multirow{2}{*}{13.6} & \multirow{2}{*}{$\begin{array}{l}13.6 \\
13.5\end{array}$} & \\
\hline CSTT097 $^{\mathrm{c}}$ & & 0000 & 2400 & & & \\
\hline CSTT098 & $7 / 12 / 1996$ & 0000 & 2400 & 5.0 & - & \\
\hline CSTT101 & \multirow{2}{*}{$7 / 15 / 1996$} & 0000 & 0000 & \multirow{2}{*}{ - } & \multirow{2}{*}{$\begin{array}{l}- \\
-\end{array}$} & Pump did not start \\
\hline CSTT102 $^{\mathrm{c}}$ & & 0000 & 0004 & & & Pump did not start \\
\hline CSTT103 & $7 / 19 / 1996$ & 0000 & 0013 & - & - & Pump did not start \\
\hline CSTT105 & \multirow{2}{*}{$7 / 22 / 1996$} & 0000 & 1636 & \multirow{2}{*}{6.7} & \multirow{2}{*}{$\begin{array}{l}6.2 \\
7.1\end{array}$} & Short sample/ Pump stopped after 16 hours \\
\hline CSTT106 $^{\mathrm{c}}$ & & 0000 & 2400 & & & \\
\hline CSTT107 & $7 / 26 / 1996$ & 0000 & 2400 & 39.8 & - & \\
\hline \multirow{7}{*}{$\begin{array}{l}\text { CSTT109 } \\
\text { CSTT110 }^{\mathrm{c}} \\
\end{array}$} & \multirow{2}{*}{$7 / 29 / 1996$} & 0000 & 2400 & \multirow{2}{*}{12.7} & \multirow{2}{*}{$\begin{array}{c}9.2 \\
16.3 \\
\end{array}$} & \\
\hline & & 0000 & 2400 & & & \\
\hline & & \multicolumn{2}{|c|}{ Average } & 115 & & \\
\hline & & \multicolumn{2}{|c|}{ Std. Dev. } & 8.1 & & \\
\hline & & \multicolumn{2}{|c|}{ Maximum } & 39.8 & & \\
\hline & & \multicolumn{2}{|c|}{ Minimum } & 2.7 & & \\
\hline & & \multicolumn{2}{|c|}{ Number } & 24 & & \\
\hline
\end{tabular}

${ }^{a}$ For period, uncertainty for sample is $2.7 \times\left(1440 /\right.$ minutes of exposure) $\mu \mathrm{g} / \mathrm{m}^{3}$

b Sample day concentration from either single sample or from average of collocated concentrations

${ }^{c}$ Collocated sample 
Table A-3. Ambient Concentrations of Airborne $\mathrm{PM}_{10}$ at Clean Slate Background Site, TTR, 2 August 1996 to 28 October $1996^{\mathrm{a}}$.

\begin{tabular}{|c|c|c|c|c|c|c|}
\hline \multirow{2}{*}{ Filter ID } & \multirow{2}{*}{$\begin{array}{l}\text { Sampling } \\
\text { Date }\end{array}$} & Sam & Period & \multirow{2}{*}{$\begin{array}{c}\text { Sample day } \\
\text { Concentration }^{\mathrm{b}} \\
\mu \mathrm{g} / \mathrm{m}^{3}\end{array}$} & \multirow{2}{*}{$\begin{array}{c}\text { Collocated } \\
\text { Filter Concentration } \\
\mu \mathrm{g} / \mathrm{m}^{3} \\
\end{array}$} & \multirow{2}{*}{ Comments } \\
\hline & & \multicolumn{2}{|c|}{ HHMM to HHMM } & & & \\
\hline CSTT111 & $8 / 2 / 1996$ & 0000 & 2400 & 9.1 & - & \\
\hline CSTT113 & \multirow{2}{*}{ 8/5/1996 } & 0000 & 2400 & \multirow{2}{*}{7.6} & 8.1 & \\
\hline CSTT114 $^{\mathrm{c}}$ & & 0000 & 0722 & & 7.0 & Short sample/ Pump stopped after 7 hours \\
\hline CSTT115 & 8/9/1996 & 0000 & 2400 & 6.7 & - & \\
\hline CSTT117 & \multirow{2}{*}{$8 / 12 / 1996$} & 0000 & 2400 & \multirow{2}{*}{12.8} & 12.6 & \\
\hline CSTT118 & & 0000 & 2400 & & 13.0 & \\
\hline CSTT119 & $8 / 16 / 1996$ & 0000 & 2400 & 12.3 & - & \\
\hline CSTT121 & \multirow{2}{*}{ 8/19/1996 } & 0000 & 2400 & \multirow{2}{*}{13.5} & 13.4 & \\
\hline $\mathrm{CSTT}_{122^{\mathrm{c}}}$ & & 0000 & 2400 & & 13.5 & \\
\hline CSTT123 & $8 / 23 / 1996$ & 0000 & 2400 & 7.1 & - & \\
\hline CSTT125 & \multirow{2}{*}{$8 / 26 / 1996$} & 0000 & 1208 & \multirow{2}{*}{6.3} & \multirow{2}{*}{$\begin{array}{l}7.0 \\
5.6\end{array}$} & Short sample/ Pump stopped after 12 hours \\
\hline $\mathrm{CSTT}_{126^{\mathrm{c}}}$ & & 0000 & 2400 & & & \\
\hline CSTT127 & $8 / 30 / 1996$ & 0000 & 2400 & 9.0 & - & \\
\hline CSTT129 & \multirow{2}{*}{ 9/2/1996 } & 0000 & 0553 & \multirow{2}{*}{15.4} & 17.2 & Short sample/ Pump stopped after 5 hours \\
\hline CSTT130 & & 0000 & 2400 & & 13.5 & \\
\hline CSTT131 & 9/6/1996 & 0000 & 2400 & 5.8 & - & \\
\hline CSTT133 & \multirow{2}{*}{ 9/9/1996 } & 0000 & 2400 & \multirow{2}{*}{5.8} & 6.0 & \\
\hline $\mathrm{CSTT}_{134^{\mathrm{c}}}$ & & 0000 & 2400 & & 5.5 & \\
\hline CSTT135 & 9/13/1996 & 0000 & 0554 & 5.3 & - & Short sample/ Pump stopped after 5 hours \\
\hline CSTT137 & \multirow{2}{*}{$9 / 16 / 1996$} & 0000 & 2400 & \multirow{2}{*}{5.7} & 6.6 & \\
\hline $\mathrm{CSTT}^{2} 138^{\mathrm{c}}$ & & 0000 & 2400 & & 4.8 & \\
\hline CSTT139 & 9/20/1996 & 0000 & 2400 & 8.0 & - & \\
\hline CSTT141 & \multirow{2}{*}{$9 / 23 / 1996$} & 0000 & 2400 & \multirow{2}{*}{7.4} & 4.4 & \\
\hline CSTT142 $^{\mathrm{C}}$ & & 0000 & 2400 & & 10.5 & \\
\hline CSTT143 & $9 / 27 / 1996$ & 0000 & 2400 & 1.7 & - & \\
\hline
\end{tabular}


Table A-3. Ambient Concentrations of Airborne $\mathrm{PM}_{10}$ at Clean Slate Background Site, TTR, 2 August 1996 to 28 October $1996^{\mathrm{a}}$ (continued).

\begin{tabular}{|c|c|c|c|c|c|c|}
\hline \multirow{2}{*}{ Filter ID } & \multirow{2}{*}{$\begin{array}{l}\text { Sampling } \\
\text { Date }\end{array}$} & \multicolumn{2}{|c|}{ Sampling Period } & \multirow{2}{*}{$\begin{array}{c}\text { Sample day } \\
\text { Concentration }^{\mathrm{b}} \\
\mu \mathrm{g} / \mathrm{m}^{3}\end{array}$} & \multirow{2}{*}{$\begin{array}{c}\text { Collocated } \\
\text { Filter Concentration } \\
\mu \mathrm{g} / \mathrm{m}^{3}\end{array}$} & \multirow{3}{*}{$\begin{array}{c}\text { Comments } \\
\text { Short sample/ Pump stopped after } 6 \text { hours }\end{array}$} \\
\hline & & \multicolumn{2}{|c|}{ HHMM to HHMM } & & & \\
\hline CSTT145 & \multirow{2}{*}{$9 / 30 / 1996$} & 0000 & 0558 & \multirow{2}{*}{5.2} & \multirow{2}{*}{$\begin{array}{l}7.5 \\
3.0\end{array}$} & \\
\hline CSTT146 $^{\mathrm{c}}$ & & 0000 & 2400 & & & \\
\hline CSTT147 & $10 / 4 / 1996$ & 0000 & 2400 & 7.8 & - & \\
\hline CSTT149 & \multirow{2}{*}{$10 / 7 / 1996$} & 0000 & 2400 & \multirow{2}{*}{5.5} & 5.6 & \\
\hline CSTT151 ${ }^{\mathrm{c}}$ & & 0000 & 2400 & & 5.3 & \\
\hline CSTT152 & $10 / 11 / 1996$ & 0000 & 2400 & 8.5 & - & \\
\hline CSTT154 & \multirow{2}{*}{$10 / 14 / 1996$} & 0000 & 2400 & \multirow{2}{*}{4.2} & 6.9 & \\
\hline $\mathrm{CSTT}^{2} 155^{\mathrm{c}}$ & & 0000 & 2400 & & 1.6 & \\
\hline CSTT156 & 10/18/1996 & 0000 & 1231 & 0.8 & - & Short sample/ Pump stopped after 12 hours \\
\hline CSTT158 & \multirow{2}{*}{$10 / 21 / 1996$} & 0000 & 2400 & \multirow{2}{*}{1.7} & 1.3 & \\
\hline $\mathrm{CSTT}_{159^{\mathrm{c}}}$ & & 0000 & 2400 & & 2.1 & \\
\hline CSTT160 & $10 / 25 / 1996$ & 0000 & 2400 & 11.5 & - & \\
\hline CSTT162 & \multirow{2}{*}{$10 / 28 / 1996$} & 0000 & 2400 & \multirow{2}{*}{2.1} & 2.7 & \\
\hline \multirow[t]{6}{*}{ CSTT163 $^{\mathrm{c}}$} & & 0000 & 2400 & & 1.5 & \\
\hline & & \multicolumn{2}{|c|}{ Average } & 7.2 & & \\
\hline & & \multicolumn{2}{|c|}{ Std. Dev. } & 3.7 & & \\
\hline & & \multicolumn{2}{|c|}{ Maximum } & 15.4 & & \\
\hline & & \multicolumn{2}{|c|}{ Minimum } & 0.8 & & \\
\hline & & \multicolumn{2}{|c|}{ Number } & 26 & & \\
\hline
\end{tabular}

${ }^{a}$ For period, uncertainty for sample is $3.3 \times\left(1440 /\right.$ minutes of exposure) $\mu \mathrm{g} / \mathrm{m}^{3}$

b Sample day concentration from either single sample or from average of collocated concentrations

${ }^{c}$ Collocated sample 
Table A-4. Ambient Concentrations of Airborne $\mathrm{PM}_{10}$ at Clean Slate Background Site, TTR, 1 November 1996 to 7 February $1997^{\mathrm{a}}$.

\begin{tabular}{|c|c|c|c|c|c|c|}
\hline \multirow{2}{*}{ Filter ID } & \multirow{2}{*}{$\begin{array}{l}\text { Sampling } \\
\text { Date }\end{array}$} & \multicolumn{2}{|c|}{ Sampling Period } & \multirow{2}{*}{$\begin{array}{c}\text { Sample day } \\
\text { Concentration } \\
\mu \mathrm{g} / \mathrm{m}^{3}\end{array}$} & \multirow{2}{*}{$\begin{array}{c}\text { Collocated } \\
\text { Filter Concentration } \\
\mu \mathrm{g} / \mathrm{m}^{3}\end{array}$} & \multirow{2}{*}{ Comments } \\
\hline & & \multicolumn{2}{|c|}{ HHMM to HHMM } & & & \\
\hline CSTT164 & $11 / 1 / 1996$ & 0000 & 2400 & 2.4 & - & \\
\hline CSTT166 & \multirow{2}{*}{$11 / 4 / 1996$} & 0000 & 2400 & \multirow{2}{*}{2.8} & 2.0 & \\
\hline CSTT167 $^{\mathrm{C}}$ & & 0000 & 1725 & & 3.6 & Short sample/ Pump stopped after 17 hours \\
\hline CSTT168 & $11 / 8 / 1996$ & 0000 & 0300 & 3.3 & - & Short sample/ Pump stopped after 3 hours \\
\hline CSTT170 & \multirow{2}{*}{$11 / 11 / 1996$} & 0000 & 1030 & \multirow{2}{*}{1.5} & 1.3 & Short sample/ Pump stopped after 10.5 hours \\
\hline CSTT171 $^{\mathrm{c}}$ & & 0000 & 2400 & & 1.7 & \\
\hline CSTT173 & $11 / 15 / 1996$ & 0000 & 2400 & 0.8 & - & Filter damaged, part of filter torn by holder. \\
\hline CSTT174 & \multirow{2}{*}{$11 / 18 / 1996$} & 0000 & 2400 & \multirow{2}{*}{3.3} & 3.9 & \\
\hline CSTT175 $^{\mathrm{c}}$ & & 0000 & 2400 & & 2.6 & \\
\hline CSTT177 & $11 / 22 / 1996$ & 0000 & 2400 & 0.3 & - & \\
\hline CSTT178 & \multirow{2}{*}{$11 / 25 / 1996$} & 0000 & 0629 & \multirow{2}{*}{1.5} & \multirow{2}{*}{$\begin{array}{l}1.0 \\
2.0\end{array}$} & Short sample/ Pump stopped after 6.5 hours \\
\hline CSTT179 $^{c}$ & & 0000 & 2400 & & & \\
\hline CSTT181 & $11 / 29 / 1996$ & 0000 & 0850 & 2.3 & - & Short sample/ Pump stopped after 9 hours \\
\hline CSTT182 & \multirow{2}{*}{$12 / 2 / 1996$} & 0000 & 2400 & \multirow{2}{*}{2.1} & 1.8 & \\
\hline CSTT183 $^{\mathrm{c}}$ & & 0000 & 2400 & & 2.4 & \\
\hline CSTT184 & $12 / 6 / 1996$ & 0000 & 0000 & - & - & Pump did not start \\
\hline CSTT186 & \multirow{2}{*}{$12 / 9 / 1996$} & 0000 & 2400 & \multirow{2}{*}{3.1} & 3.1 & \\
\hline CSTT187 $^{\mathrm{c}}$ & & 0000 & 2400 & & 3.1 & \\
\hline CSTT188 & $12 / 13 / 1996$ & 0000 & 2400 & 8.1 & - & \\
\hline CSTT190 & \multirow{2}{*}{$12 / 16 / 1996$} & 0000 & 0000 & \multirow{2}{*}{4.5} & - & Pump did not start \\
\hline CSTT191 $^{\mathrm{c}}$ & & 0000 & 2400 & & 4.5 & Ran for 2.21 days, $12 / 16-18$ \\
\hline CSTT192 & $12 / 20 / 1996$ & 0000 & 2400 & 3.2 & - & Ran 12/20 0000-2400; 12/27 0000-1115 \\
\hline CSTT194 & \multirow{2}{*}{$12 / 23 / 1996$} & 0000 & 0016 & \multirow{2}{*}{4.2} & \multirow{2}{*}{$\begin{array}{c}- \\
4.2\end{array}$} & Pump did not start \\
\hline CSTT195 & & 0000 & 2400 & & & Ran for 2.25 days, $12 / 23-25$ \\
\hline CSTT196 & $12 / 27 / 1996$ & 1130 & 2400 & 7.8 & - & Late start \\
\hline CSTT198 & \multirow{2}{*}{$12 / 30 / 1996$} & 0000 & 2400 & \multirow{2}{*}{2.1} & 2.2 & \\
\hline CSTT199 $^{c}$ & & 0000 & 2400 & & 2.0 & \\
\hline
\end{tabular}


Table A-4. Ambient Concentrations of Airborne PM $_{10}$ at Clean Slate Background Site, TTR, 1 November 1996 to 7 February $1997^{\mathrm{a}}$ (continued).

\begin{tabular}{|c|c|c|c|c|c|c|}
\hline \multirow{2}{*}{ Filter ID } & \multirow{2}{*}{$\begin{array}{l}\text { Sampling } \\
\text { Date }\end{array}$} & \multicolumn{2}{|c|}{ Sampling Period } & \multirow{2}{*}{$\begin{array}{c}\text { Sample day } \\
\text { Concentration }^{\mathrm{b}} \\
\mu \mathrm{g} / \mathrm{m}^{3}\end{array}$} & \multirow{2}{*}{$\begin{array}{c}\text { Collocated } \\
\text { Filter Concentration } \\
\mu \mathrm{g} / \mathrm{m}^{3}\end{array}$} & \multirow{2}{*}{ Comments } \\
\hline & & \multicolumn{2}{|c|}{ HHMM to HHMM } & & & \\
\hline CSTT201 & $1 / 3 / 1997$ & 0000 & 2400 & 0.6 & - & \\
\hline CSTT203 & \multirow{2}{*}{ 1/6/1997 } & 0000 & 0000 & \multirow{2}{*}{4.6} & \multirow{2}{*}{$\begin{array}{c}- \\
4.6\end{array}$} & Pump did not start \\
\hline $\mathrm{CSTT}_{204^{\mathrm{C}}}$ & & 0000 & 2400 & & & \\
\hline CSTT205 & $1 / 10 / 1997$ & 0000 & 2400 & 0.3 & - & \\
\hline CSTT207 & \multirow{2}{*}{$1 / 13 / 1997$} & 0000 & 2400 & \multirow{2}{*}{4.2} & \multirow{2}{*}{$\begin{array}{c}4.2 \\
- \\
\end{array}$} & \\
\hline CSTT208 ${ }^{\mathrm{c}}$ & & 0000 & 0205 & & & Short sample/ Pump stopped after 2 hours \\
\hline CSTT209 & $1 / 17 / 1997$ & 0000 & 0700 & 1.9 & - & Short sample/ Pump stopped after 7 hours \\
\hline CSTT211 & \multirow{2}{*}{$1 / 20 / 1997$} & 0000 & 2400 & \multirow{2}{*}{2.0} & \multirow{2}{*}{$\begin{array}{c}1.9 \\
- \\
\end{array}$} & \\
\hline $\mathrm{CSTT}_{212^{\mathrm{c}}}$ & & 0000 & 0110 & & & Short sample/ Pump stopped after 1 hour \\
\hline CSTT213 & $1 / 24 / 1997$ & 0000 & 2400 & 1.9 & - & \\
\hline CSTT215 & \multirow{2}{*}{$1 / 27 / 1997$} & 0000 & 0410 & \multirow{2}{*}{2.2} & \multirow{2}{*}{2.} & Short sample/ Pump stopped after 4 hours \\
\hline $\mathrm{CSTT} 216^{\mathrm{c}}$ & & 0000 & 2400 & & & \\
\hline CSTT218 & $1 / 31 / 1997$ & 0000 & 2400 & 3.5 & - & \\
\hline CSTT220 & \multirow{2}{*}{ 2/3/1997 } & 0000 & 0034 & \multirow{2}{*}{2.8} & - & Short sample/ Pump stopped after 0.5 hour \\
\hline $\mathrm{CSTT} 219^{\mathrm{c}}$ & & 0000 & 2400 & & 2.8 & \\
\hline CSTT221 & 2/7/1997 & 0000 & 2400 & 2.5 & - & Ran 2/7 0000-2400, 2/14 0000-2400 \\
\hline CSTT223 & \multirow{2}{*}{ 2/7/1997 } & 0000 & 0004 & \multirow{2}{*}{4.1} & \multirow{2}{*}{$\begin{array}{c}- \\
4.1 \\
\end{array}$} & Pump did not start \\
\hline \multirow[t]{6}{*}{$\mathrm{CSTT}_{224^{\mathrm{c}}}$} & & 0000 & 2400 & & & $\operatorname{Ran} 2 / 7$ 0000-2400, 2/14 0000-2400 \\
\hline & & \multicolumn{2}{|c|}{ Average } & 2.9 & & \\
\hline & & \multicolumn{2}{|c|}{ Std. Dev. } & 1.9 & & \\
\hline & & \multicolumn{2}{|c|}{ Maximum } & 8.1 & & \\
\hline & & \multicolumn{2}{|c|}{ Minimum } & 0.3 & & \\
\hline & & \multicolumn{2}{|c|}{ Number } & 26 & & \\
\hline
\end{tabular}

${ }^{a}$ For period, uncertainty for sample is $1.3 \times(1440 /$ minutes of exposure $) \mu \mathrm{g} / \mathrm{m}^{3}$

b Sample day concentration from either single sample or from average of collocated concentrations

c Collocated sample 